\title{
Can Early Electrical Stimulation Accelerates the Neural Regeneration by Increasing the Expression of BDNF and GDNF in Distal Part of Injured Peripheral Nerve? An Animal Experimental Study
}

\author{
Agus Roy Rusly Hariantana Hamid ${ }^{1 *}$ (D), Sri Maliawan ${ }^{2}$ D, DPG Purwa Samatra ${ }^{3}$ D, I Nyoman Mantik Astawa ${ }^{4}$, \\ I Made Bakta ${ }^{5}$ (D) I Made Jawi ${ }^{6}$, Ida Bagus Putra Manuaba ${ }^{7}$, I Dewa Made Sukrama ${ }^{8}$, David Sontani Perdanakusuma ${ }^{9}$ id \\ ${ }^{1}$ Department of Surgery, Division of Plastic Reconstructive and Aesthetic Surgery, Faculty of Medicine, Udayana University, \\ Sanglah General Hospital Bali, Denpasar, Indonesia; '2Department of Neurosurgery, Division of Neurosurgery, Faculty of \\ Medicine, Udayana University, Sanglah General Hospital Bali, Denpasar, Indonesia; ${ }^{3}$ Department of Neurology, Faculty of \\ Medicine, Udayana University, Sanglah General Hospital Bali, Denpasar, Indonesia; ${ }^{4}$ Department of Animal Disease, Faculty \\ of Veterinary Medicine, Udayana University, Bali, Indonesia; ${ }^{5}$ Department of Internal Medicine, Division of Haematology and \\ Oncology, Faculty of Medicine, Udayana University, Sanglah General Hospital Bali, Denpasar, Indonesia; ${ }^{6}$ Department of \\ Pharmacology and Therapy, Faculty of Medicine, Udayana University, Bali, Indonesia; 'Department of Chemistry, Udayana \\ University, Bali, Indonesia; ${ }^{8}$ Department of Clinical Microbiology, Faculty of Medicine, Udayana University, Bali, Indonesia; \\ ${ }^{9}$ Department of Plastic Reconstructive and Aesthethic Surgery, Faculty of Medicine, Universitas Airlangga, Surabaya, Indonesia
}

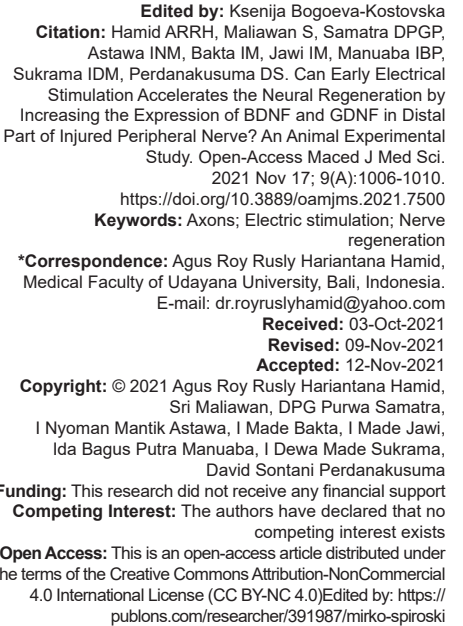

Edited by: Ksenija Bogoeva-Kostovska
Citation: Hamid ARRH, Maliawan S Samatra DPGP, Astawa INM, Bakta IM, Jawi M, Manuaba Stimulation Accelerates the Neural Regeneration by Increasing the Expression of BDNF and GDNF in Dista Study 2021 Nov 17: 9(A):1006-1010 htps://doi 20210 . 388 17: https://doi.org/10.3889/oamjms.2021.7500 regeneration *Correspondence: Agus Roy Rusly Hariantana Hamid, Udayana University, Bali, Indonesia. Received: 03-Oct-2021 Revised: 09-Nov-202 Copyright: ๑ 2021 Agus Roy Rusly Hariantana Hamid Si Maliawan, DPG Purwa Samatr, uaba, I Dewa Made Sukrama, David Sontani Perdanakusuma Competing Interest: The authors have declared that no Open Access: This is an open-access article distributed under 4.0 International License (CC BY-NC 4.0)Edited by h htps publons.com/researcher/391987/mirko-spirosk

\begin{abstract}
BACKGROUND: The role of neurotrophic factors (brain-derived neurotrophic factors and glial cell line-derived neurotrophic factors) and early electrical stimulation (EES) in the injured nerve has found promising in severa studies. However, there is still limited knowledge about the effect of EES in the distal part of the nerve to sustain this level of expression of growth factors.

AIM: We aim to evaluate the effects of EES in in neural regeneration by measuring the expression of brain-derived neurotrophic factor (BDNF) and glial cell line-derived neurotrophic factor (GDNF) in animal model.

METHODS: The research was conducted starting from April to May 2021 using male Wistar rats. Using general anesthesia, the sciatic nerve was cut. The intervention group was treated with EES in the distal stump, right afte nerve resection $(20 \mathrm{~Hz}, 1-2 \mathrm{~mA}, 2-5 \mathrm{~s})$, while the control group received no treatment after nerve resection. A reoperation on day 3 was performed in both groups to measure BDNF and GDNF expression level of the dista nerve tissue by ELISA as well as histopathological examination of sprouting axons of the injured proximal nerve.

RESULTS: A total of 32 samples were included in the study. A statistically significant levels of GDNF is found higher in the EES group $(n=16)$ than the control group $(n=16)(35.71 \mathrm{pg} / 100 \mathrm{mg}$, confidence interval $(\mathrm{Cl}) 95 \% 23.93$ $47.48, p<0.05)$. The number of sprouting axons is found lower in the EES group $(p<0.05)$. The BDNF level is similar between the two groups, however not significant. After a subgroup analysis, it was found that the greater the level of GDNF, the fewer the axon sprouts in both groups (fewer axon group 58.35 [ $n=22, \mathrm{Cl} 95 \% 45.14,71.55]$ vs. more axon group 47.14 [ $n=10, \mathrm{Cl} 95 \% 35.33,58.95]), p<0.05$.
\end{abstract}

CONCLUSION: The EES proves its benefit in accelerating the axonal regeneration by increasing the expression GDNF in the distal nerve stumps in the electrical excited degenerated sciatic nerve in the rat model.

\section{Introduction}

In the adult nervous system, the role of the neurotrophic factors in neural survival and capacity for axon regeneration has also been the subject of considerable investigation both with nerve injuries. Peripheral nerve injury is still a health problem that often results in functional disorders despite the advancing therapies with surgery and physiotherapy. Brainderived neurotrophic factor (BDNF) and glial cell linederived neurotrophic factor (GDNF) are two of the most investigated neurotrophic factors that proved their roles as crucial modulators of axon regeneration [1]. Their functions in nerve regulation and signaling are well documented, as well as its role in activity-dependent treatments including electrical stimulation [1], [2], [3]. One of the established therapies for peripheral nerve injury is the electrical stimulation to the proximal nerve segment, potentially causing excessive axonal sprouting growth in the proximal part of the nerve if it is not accompanied by an acceleration of the Wallerian degeneration in the distal part of the nerve [4], [5], [6], [7], [8].

Several studies have also shown that electrical stimulation may also affect the behavior 
of Schwann cells by increasing cellular proliferation and intracellular nerve growth factor expression in vitro as well as remyelination of injured axons in vivo, mediated by increased expression of BDNF [2], [9]. To date, there is no published study about the electrical stimulation of the distal part after nerve injury to accelerate the Wallerian degeneration and its effect in axonal regeneration. We measured the expression of these motoneuron BDNF and GDNF in the animal model with immediate electrical stimulation to the distal nerve versus no electrical stimulation after sciatic nerve resection to figure out if the treatment can sustain the neurotrophic factors. We measured the expression of BDNF and GDNF in the distal nerve stumps to investigate the electrical excited degenerated nerve effects on the axonal regeneration.

\section{Research Design and Methods}

This is an experimental laboratory study using animal model with Randomized Post-Test Only Control Group Design. The research was conducted for 1 month starting from April to May 2021 at the integrated biomedical laboratory unit, faculty of medicine, Udayana University, Denpasar, as a place for rat care and treatment, Veterinary Pathology Laboratory, Faculty of Veterinary Medicine, Udayana University, as a place for ELISA examination of BDNF and GDNF, and Anatomical Pathology Department, Faculty of Medicine, Udayana University/Sanglah General Hospital, Denpasar, as a place for histopathological examination of sprouting axon. Samples were taken from an accessible population with following criteria: Male Wistar rat, age 8-12 weeks (2-3 months), weight 150-200 g. And the exclusion criteria: Rat that unwilling to eat and unhealthy (inactive motion), which was confirmed by veterinary examination [10]. Dropout criteria are rat that died during the study and when the exclusion factors occur during the study.

The independent variable was the immediate electrical stimulation. The dependent variables were the response/effect measuring the expression of BDNF and GDNF as the primary outcome, and the number of sprouting axons as the secondary outcome. The controlled variables were sex, health, age, body weight, food, and environmental conditions.

The use and care of the rats for this research complied to the ethical standard in accordance with the ethical clearance certificate No:132/ UN14.2.2.VII.14/LT/2021, issued by the ethical committee and scientific coordinator of research in health section, Faculty of Medicine, Udayana University. The research was also performed in accordance with Helsinki Declaration rules, stated that the research must be performed by people who have been trained and the experimental animals must be treated in comfortable environment.

\section{Research procedure}

Anesthesia was given with the aim of not causing any pain to experimental animals. Rats were anesthetized using ketamine $(100 \mathrm{mg} / \mathrm{ml}) 2.5 \mathrm{ml}$, xylazine $(20 \mathrm{mg} / \mathrm{ml}) 2.5 \mathrm{ml}$, and acepromazine $(10 \mathrm{mg} /$ $\mathrm{ml}) 1 \mathrm{ml}$ dissolved in $4 \mathrm{ml}$ sterile water (total volume $10 \mathrm{ml}$ ) and injected intramuscularly, then the rats were shaved at dorsal region of the femur. In the prone position, a skin incision was made at dorsal region of the femur and parallel blunt dissection was performed to separate the femur muscle, then identification of sciatic nerve which was located inferiorly and inside the femur was performed.

After the sciatic nerve was identified, the sciatic nerve was cut. Rats in Group 1 were treated with immediate electrical stimulation of the distal nerve, right after the sciatic nerve was cut $(20 \mathrm{~Hz}, 1-2 \mathrm{~mA}$, duration 2-5 s). Rats in Group 2 were the control group which the wound was closed without any treatment after the sciatic nerve was cut, thus the nerve was allowed to heal naturally.

Three days after the nerve transection, a reoperation was performed to get nerve tissue sample for examination of BDNF and GDNF of the distal nerve by ELISA method as well as histopathological examination of sprouting axons of the injured proximal nerve.

The data for the expression of BDNF, GDNF, and the number of sprouting axons were tested for normality using the Shapiro-Wilk test, independent t-test for parametric and Mann-Whitney for nonparametric analysis with significance at the $5 \%$ level ( $p$ $<0.05$ ) using IBM SPSS version 23.

\section{Results}

A total of 32 samples were included in the study, divided evenly into control and early electrical stimulation (EES) group of 16 samples. Two rats in the study group and two in the control group were excluded due to unfitness. The level of BDNF and GDNF was measured using ELISA test on day 3 post nerve resection (Table 1). The histopathological examination of sprouting axons of the injured proximal nerve is shown in Figure 1.

After statistical analysis of the level of growth factor in the tissue, there is no significant difference in the BDNF axonal tissue level between the two groups (154.43 interquartile range [IQR] 136.29-172.57) vs. 154.43 (IQR 138.67-170.19, $p>0.05)$. The 
mean GDNF level was measured in the EES group which was 81.3632 (confidence interval $(\mathrm{Cl}) 95 \%$ $23.93,47.48)$, while the control group was 45.6519 (Cl 95\% 23.93, 47.48). The mean difference in the GDNF axonal tissue level is 35.71 (Cl 95\% 23.93, $47.48, p<0.05)$. The median number of sprouting axon was 2.5 (IQR 2-3) in the control group and 2 (IQR 1-2), $p<0.05$. The distribution of BDNF and GDNF according to the number of sprouting is shown in Figure 2. In the subgroup analysis of fewer (lower than median) versus higher sprouting axon group, the median BDNF level was measured $149.59(\mathrm{n}=22$, IQR 121.11, 178.06), and $161.78(\mathrm{n}=10$, IQR 147.82, 175.74), $p>0.05$, respectively. In the subgroup analysis of GDNF, the mean in the lower sprouting group was 58.35 ( $\mathrm{n}=22, \mathrm{Cl} 95 \% 45.14,71.55)$, and greater sprouting group was $47.14(\mathrm{n}=10, \mathrm{Cl} 95 \%$ 35.33, 58.95), $p<0.05$ (Table 2).

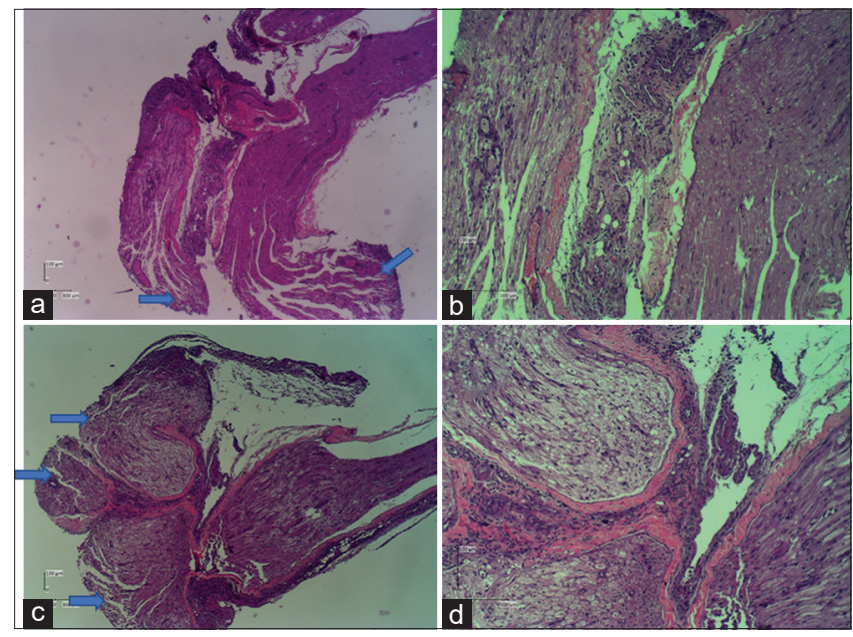

Figure 1: A histopathological sample of distal stump of axon in the EES group (a) and (b) was found fewer sprouting axon than in the control group (c) and (d) (showed by arrow), (longitudinal section, a and $c 40 \times, b$ and $c$ 100x)

\section{Discussion}

A statistically significant level of GDNF is found higher in the EES group than the control group (35.71, Cl $95 \%$ 23.93, 47.48, $p<0.05)$. On the contrary, the number of sprouting axons is found lower in the EES group, which is statistically significant after analysis. The BDNF level is similar between the two groups, however not significant. After a subgroup analysis, it was found that the greater the level of GDNF, the fewer the axon sprout in both groups (fewer axon group 58.35 [ $\mathrm{n}=22, \mathrm{Cl}$ $95 \% 45.14,71.55]$ vs. more axon group $47.14[\mathrm{n}=10, \mathrm{Cl}$ $95 \%$ 35.33, 58.95], $p<0.05)$.

Schwann cells and macrophages are two of the main orchestrators of the axonal regeneration. In the regeneration process, the growth of axon is to grow in single columnal fibers of neurons, before the myelinization took process [11]. If the newly sprout does not achieve the distal stump in a single column, the sprouts go uncontrollably and become neuroma [3]. Therefore, a coordinated activity of cytokines during the axonal degeneration and regeneration is imperative, in which both processes could overlap or taking turns [8], [12].

It is known that the Schwann cells are regulated by variety of hormones and molecules such as neuregulin, cAMP, ascorbic acid, and transcription factors SCIP and Krox-20 [13], [14]. After the Wallerian degeneration resolves the debris and necrotic tissues in the injured area, the myelinization took process, and the neutrophic factor expression was increased, which also regulated by the Schwann cells [13]. The neurotrophic secretion is produced by bone marrow, perineural glial, and motor neuron. These neurotrophic growth factors activate Schwann cells to further induce the production of growth factors in proximal part and to be a bridge over the neurotmesis in 5 days [2].

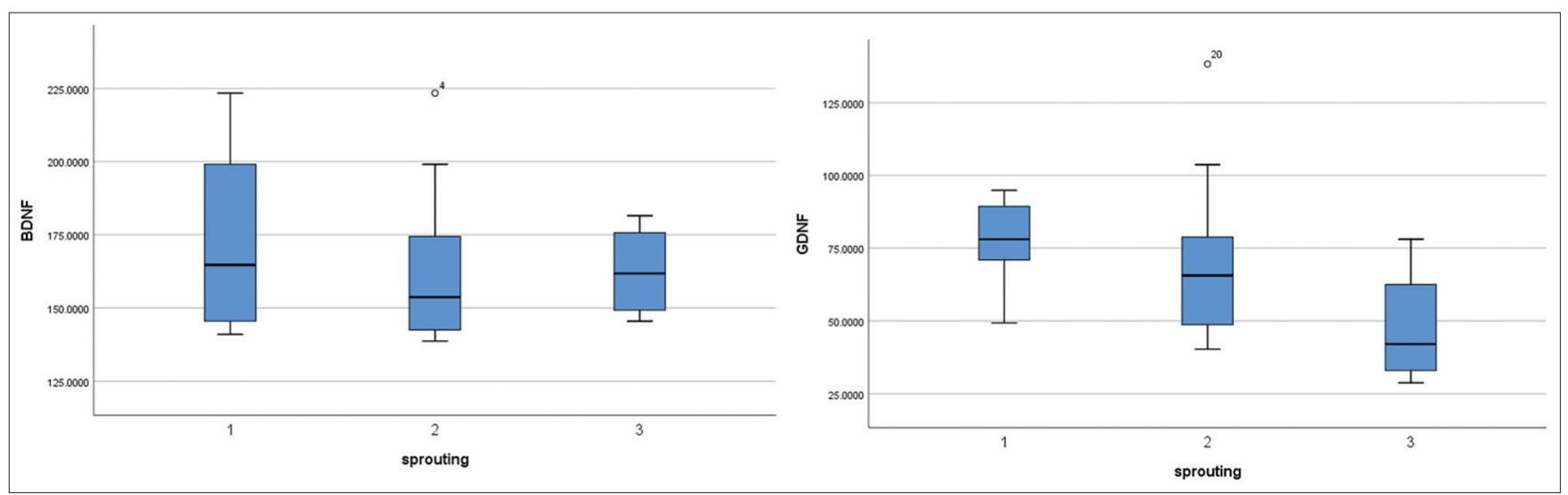

Figure 2: The distribution of expression level of BDNF (left) and GDNF (right) with the number of sprouting axon

Table 1: Measurements of the BDNF and GDNF levels in the distal stump of axotomized rats

\begin{tabular}{llll}
\hline Variables & Control group $(n=16)$ & EES group $(n=16)$ & Statistic test \\
\hline BDNF & $154.43($ IQR 136.29-172.57) & $154.43($ IQR 138.67-170.19) & p-value \\
GDNF & $45.6519(\mathrm{Cl} 95 \%$ 23.93, 47.48) & $81.3632(\mathrm{Cl} 95 \%$ 23.93, 47.48) & 0.880 \\
Sprouting axon & $2.5($ IQR 2-3) & 2 (IQR 1-2) & $35.71(\mathrm{Cl} \mathrm{95 \%} \mathrm{23.93,47.48)}$ \\
\hline BDNF: Brain-derived neurotrophic factor, GDNF: Glial cell line-derived neurotrophic factor, Cl: Confidence interval, IQR: Interquartile range. & 0.000 \\
\hline
\end{tabular}


Table 2: Subgroup analysis of the BDNF and GDNF distributed by the number of sprouting axon

\begin{tabular}{|c|c|c|c|c|}
\hline \multirow[t]{2}{*}{ Group } & \multirow[t]{2}{*}{ All group } & \multicolumn{3}{|l|}{ Subgroup } \\
\hline & & Lower & Greater & p-value \\
\hline BDNF (median) & 154.43 (IQR 136.29-172.57) & $149.59(\mathrm{n}=22$, IQR $121.11,178.06)$ & $161.78(n=10$, IQR $147.82,175.74)$ & 0.542 \\
\hline GDNF (mean) & $63.51(n=32, \mathrm{Cl} 95 \% 54.77,72.23)$ & $58.35(n=22$, Cl 95\% 45.14, 71.55) & $47.14(n=10, \mathrm{Cl} 95 \% 35.33,58.95)$ & 0.008 \\
\hline
\end{tabular}

The BDNF is mediated by two types of receptors, first with high affinity to tropomyosin receptor kinase (trk) to transmit neurotrophic signals through multiple pathways. Second, with low affinity to the tumor necrosis factor family of receptors, the p75 neurotrophin receptor, also known as the death receptors and promotes apoptosis [15]. A contrasting role for trk and p75NTR in motor axonal regeneration has been well documented by several studies. The administration of high-dose exogenous BDNF promotes axonal growth and neuronal survival through trk. Opposingly, the axonal growth is achieved by blocking the BDNF binding to $\mathrm{p} 75 \mathrm{NTR}$ which prevents the release of pro-apoptotic p75 [3]. BDNF has the effect of bimodal with lower doses that work through the TrkB receptor to encourage the regeneration of axons, while higher doses work through p75 to inhibit the regeneration of axon [1], [3], [16].

The GDNF binds to glycosylphosphatidylinositol membrane-linked receptor subunit, GDNF-family receptor-1 (GFR-1), and a signal transducing tyrosine kinase subunit, Ret. With the help of coreceptor GFR$\alpha$, the GDNF played a critical role as axonal growth cone guidance after the Wallerian degeneration in axotomized nerve [17].

The electrical stimulation increased intracellular cyclic adenosine monophosphate (cAMP) directly. Once the BDNF binds to trk, cAMP begins the transcription and translation process and upregulates the whole process until the axonal gap is closed [4]. In their study, Willand et al. analyzed a portion of medial gastrocnemius muscle after tibial nerve transection. The group received daily electrical muscle stimulation for 2 weeks, the levels of BDNF mRNA were two fold higher than those without electrical stimulation, while levels of GDNF mRNA were 2.5-fold higher than those without electrical stimulation [7]. The expression of BDNF and GDNF mRNA was increased corresponds to the enhanced neuronal regeneration and muscle reinnervation demonstrated the critical role of the neurotrophic factors BDNF and neurotrophin 4/5 in the efficacy of the electrical stimulation effect in accelerating nerve regeneration [1]. Clinical finding of the rolipram, Type IV inhibitors of the enzyme phosphodiesterase which breaks down cAMP, promotes the growth of the central nervous system has been shown in research that is conducted by Gordon et al., which assessed whether administration of rolipram can improve the regeneration of the axons [2].

In this study, we found the increased GDNF level in the EES on day 3 after nerve resection without the increase of BDNF in the same group. This might imply stronger potential effect of the GDNF on promoting axonal regeneration in the distal stump, solely without the rise of other factors. The level of BDNF was found similar in both groups, however not significant, thus has the number of sample increased or the method repeated, the result would be significant. Our study shows that EES affects the expression of GDNF in the distal stumps thus accelerates the regeneration process. Moreover, the EES also significantly reduces the sprouting of axon. This finding supports that EES might prevents neuroma.

As many have proved the EES upregulates the expression of neurotrophic factors and their receptors, this expression is transient, fluctuating within days. The author thought that it was best perceived with repeated measurement of the growth factors, in which this study was lacking. This study observes the level and effects of growth factors in the distal stump and does not cover for the speed of regeneration which occurs in the proximal part, nor it has to do with the onset of injury (acute or chronic axonotomy). A more frequent observation of the neurotrophic factors in both the proximal and distal stump in the resected nerve should be included in future studies. Another setback of this study is the limited number sample, which excluded four samples and might influence the result.

\section{Conclusion}

The role of electrical stimulation and neurotrophic factors in neural growth and survival for axon regeneration has been proved crucial in nerve injuries. Our findings prove the benefit of the EES in accelerating the axonal regeneration by increasing the expression GDNF in the distal nerve stumps in the electrical excited degenerated sciatic nerve in the rat model.

\section{References}

1. McGregor CE, English AW. The role of BDNF in peripheral nerve regeneration: Activity-dependent treatments and val66met. Front Cell Neurosci. 2019;12:522. https://doi.org/10.3389/ fncel.2018.00522

PMid:30687012

2. Gordon T. The role of neurotrophic factors in nerve regeneration. Neurosurg Focus. 2009;26(2):E3. https://doi.org/10.3171/ FOC.2009.26.2.E3

PMid:19228105 
3. Bothwell M. Recent advances in understanding contextdependent mechanisms controlling neurotrophin signaling and function. F1000Res. 2019;8:1658. https://doi.org/10.12688/ f1000research.19174.1

\section{PMid:31583078}

4. Al-Majed AA, Brushart TM, Gordon T. Electrical stimulation accelerates and increases expression of BDNF and trkB mRNA in regenerating rat femoral motoneurons. Eur $\mathrm{J}$ Neurosci. 2000;12(12):4381-90.

PMid:11122348

5. Zuo KJ, Gordon T, Chan KM, Borschel GH. Electrica stimulation to enhance peripheral nerve regeneration: Update in molecular investigations and clinical translation. Exp Neurol. 2020;332:113397. https://doi.org/10.1016/j. expneurol.2020.113397 PMid:32628968

6. Su HL, Chiang CY, Lu ZH, Cheng FC, Chen CJ, Sheu ML, et al. Late administration of high-frequency electrical stimulation increases nerve regeneration without aggravating neuropathic pain in a nerve crush injury. BMC Neurosci. 2018;19(1):1-12. https://doi.org/10.1186/s12868-018-0437-9

PMid:29940857

7. Willand MP, Nguyen MA, Borschel GH, Gordon T. Electrical stimulation to promote peripheral nerve regeneration. Neurorehabil Neural Repair. 2016;30(5):490-6. https://doi. org/10.1177/1545968315604399

PMid:26359343

8. Nayak R, Banik RK. Current innovations in peripheral nerve stimulation. Pain Res Treat. 2018;2018:1-5. https://doi. org/10.1155/2018/9091216

PMid:30302288

9. Gordon T. Peripheral nerve regeneration and muscle reinnervation. Int J Mol Sci. 2020;21(22):8652. https://doi. org/10.3390/ijms21228652

PMid:33212795

10. Almani SA, Memon IA, Shaikh TZ, Khoharo HK, Ujjan I. Berberine protects against metformin-associated lactic acidosis in induced diabetes mellitus. Iran J Basic Med Sci. 2017;20:511-5. https:// doi.org/10.22038/IJBMS.2017.8675 PMid:28656086

11. Radtke C, Vogt PM. Peripheral nerve regeneration: A current perspective. Eplasty. 2009;9:e47.

PMid:19907643

12. Liu P, Peng J, Han GH, Ding X, Wei S, Gao G, et al. Role of macrophages in peripheral nerve injury and repair Neural Regen Res. 2019;14(8):1335-42. https://doi. org/10.4103/1673-5374.253510 PMid:30964051

13. Burnett MG, Zager EL. Pathophysiology of peripheral nerve injury: A brief review. Neurosurg Focus. 2004;16(5):1-7. https:// doi.org/10.3171/foc.2004.16.5.2

PMid:15174821

14. Tam SL, Gordon T. Mechanisms controlling axonal sprouting at the neuromuscular junction. J Neurocytol. 2003;32(5-8):961-74. https://doi.org/10.1023/B: NEUR.0000020635.41233.0f PMid:15034279

15. Sakuragi S, Tominaga-Yoshino K, Ogura A. Involvement of TrkB- and p75NTR-signaling pathways in two contrasting forms of long-lasting synaptic plasticity. Sci Rep. 2013;3(1):3185. https://doi.org/10.1038/srep03185 PMid:24212565

16. Keefe K, Sheikh I, Smith G. Targeting neurotrophins to specific populations of neurons: NGF, BDNF, and NT-3 and their relevance for treatment of spinal cord injury. Int $\mathrm{J}$ Mol Sci. 2017;18(3):548. https://doi.org/10.3390/ijms18030548 PMid:28273811

17. Ibáñez CF, Paratcha G, Ledda F. RET-independent signaling by GDNF ligands and GFR $\alpha$ receptors. Cell Tissue Res. 2020;382(1):71-82. https://doi.org/10.1007/ s00441-020-03261-2

PMid:32737575 